\title{
PROTO HISTORIC SITES IN THE JORDAN VALLEY: A CRITICAL STUDY OF THE HERITAGE ASPECTS
}

\author{
David Ben-Shlomo ${ }^{1 *}$ and Yosef Garfinkel ${ }^{2}$ \\ ${ }^{1}$ Ariel University, Israel \\ ${ }^{2}$ Hebrew University, Israel
}

\begin{abstract}
Proto historic archaeological sites (ca. 8,000-3,000 BCE Calibrated) create a special challenge for heritage management and education. These sites are usually small and do not have well preserved or impressive architecture. Furthermore, it is difficult to preserve and reconstruct these sites. In terms of public and national heritage and education these sites are also difficult to be linked to current cultures and narratives of existing communities. A case study of the Jordan Valley in Israel will be inspected with two major sites: Sha'ar Hagolan of the Late Neolithic period, and Tel Tsaf of the Middle Chalcolithic period. Both sites are relatively large and illustrate a sophisticated and complex material culture, architecture and site planning. In addition to having the challenges noted above these sites are also located in modern agricultural areas, further, impeding their preservation. The sites are currently not open for the touristic public. Possible solutions for exposure to the public and heritage management and education will be discussed. The fact that these are proto-historic sites, predating the rise of monotheistic religions in the Near East, could in fact serve as an advantage in this region, since this can bypass current political and ideological disagreements and conflicts in the Middle East which are national or religion based.
\end{abstract}

Keywords: Southern Levant, Sha'ar Hagolan, Protohistoric sites, Tel Tsaf

\section{Introduction}

Proto historic archaeological sites (ca. 8,000-3,000 BCE Calibrated) in the Near East are defined as those dating from the appearance agricultural and built settlements (the Neolithic period) and the appearance of first urban sites (the Early Bronze Age). They create a special challenge for heritage management and education. These sites are usually small and do not have well preserved architecture. One of the major problems in delivering prehistoric heritage to the public is the meagerness of archaeological remains. Unlike Roman theaters and Byzantine mosaic floors, protohistoric sites as a rule can hardly offer a significant visitor attraction. Even when the sites are relatively impressive, attracting the interest of diversified audiences, they can hardly offer more than a short, less than an hour tour, and thus they cannot sustain in themselves a full day visit. Therefore, if one wants to present prehistoric sites to the large public on a regular basis, the maintenance of the site alone is not sufficient. Therefore, creating an agglomeration of prehistory-related establishments, should reinforce the sites. Only such an agglomeration can create the 'critical mass' needed to sustain the visitor in the place for a longer period of time. Thus, developing a visiting program should include a variety of activities, and present to the visitors with a wider view of the processes occurring in human prehistory on both the chronological and geographical levels.

Two proto-historic sites in the Jordan Valley, Israel are presented here, Sha'ar Hagolan and Tel Tsaf (Fig. 1). For one of the sites, Neolithic Sha'ar Hagolan, such an agglomeration is suggested, and the paper presents both existing establishments and proposed ones (see below). The site illustrates "Neolithic Revolution" - the transition from hunters and gatherers to villages and farming. This basic and most fundamental shift in human evolution, took place in the Jordan Valley, where Sha'ar Hagolan is located. Another site to be discussed in the Jordan Valley is Tel Tsaf which was occupied later during the Middle Chalcolithic period, for which a date of 5,200-4,500 Cal BC probably illustrates another stage in social evolution where higher amounts of surplus were stored and consumed. The paper will discuss heritage aspects related to these sites. The limitations of the study 
are that it only examines two sites in one region. And that many of the aspects raised are proposed and not yet accomplished.

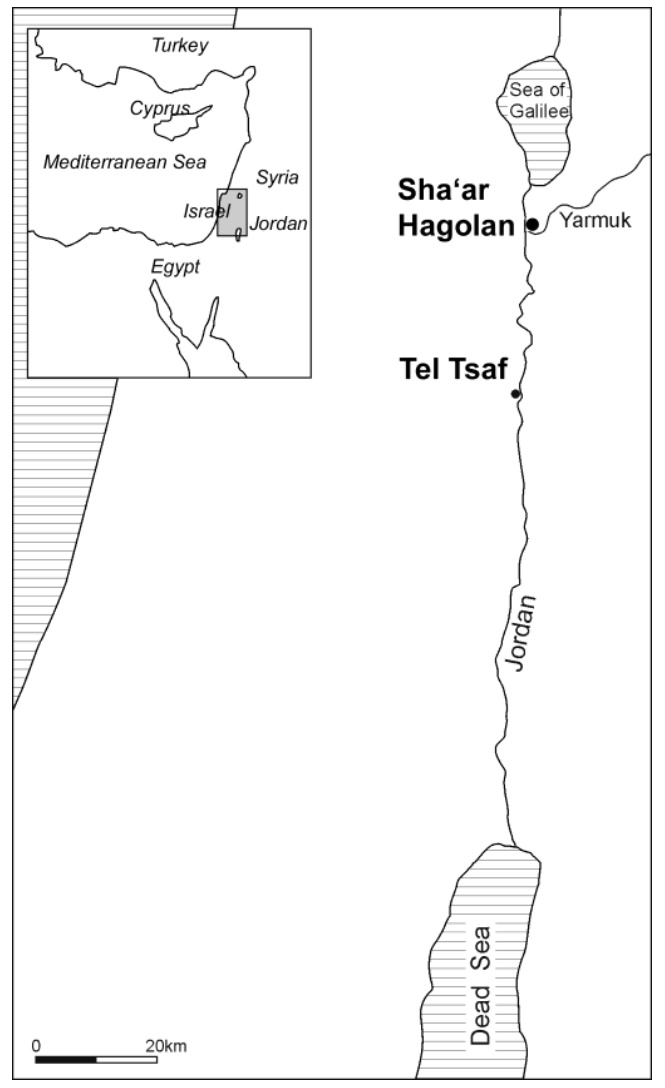

Figure 1. Map with location of the sites

\section{Sha'ar Hagolan}

The site of Sha'ar Hagolan is located in the central Jordan Valley on the northern bank of the Yarmuk river 1 mile south of the Sea of Galilee (Fig. 1). It is dated to the Pottery Neolithic period, over ca. 8,000 years ago, and is the type site for the Yarmukian culture which occupied large parts of the Mediterranean climatic zone in Israel, Jordan and Lebanon. This is one of the largest sites of its period in the Near East expanding to around 20 hectares. Sha'ar Hagolan was first discovered in the 1940's and excavated between 1949-52 by M. Stekelis (1972). Large-scale excavations have been conducted on the site for eleven seasons (1989-90, 1996-2004) on behalf on the Hebrew University of Jerusalem, directed by Y. Garfinkel. The excavation was conducted in five different fields and nearly 3,000 sq.m. were uncovered (Garfinkel and Miller, 2002; Garfinkel, 2004, Garfinkel and Ben-Shlomo, 2009; Garfinkerl et al., 2010; Garfinkil et al., 2011).

The highlights of this large site are its monumental and well-planned architecture and village planning (Garfinkel and Ben-Shlomo 2009; Garfinkel et al. 2011) (Fig. 2). The site includes large courtyard buildings: three complete buildings were excavated, two within an area of about 250 sq.m. and one within an area of 700 sq.m. (Fig. 3), one of the largest structures of its time. Plastered streets running north-south and east-west were discovered between the buildings, attesting to a highly complex and organized society. In addition a water well, $4.5 \mathrm{~m}$ deep, lined with stones, was discovered in the central area (Garfinkel, 2004, 87-99) (Fig. 4).

In addition to architecture rich assemblages of material culture were found including flint, limestone and basalt artifacts, as well as imported obsidian fragments and seashells. The people of Sha' ar Hagolan were the first to introduce the manufacturing of pottery in the region. The most famous, however, is the rich collection of 
Neolithic art objects, including some 300 figurines made of clay and stone (Garfinkel et al., 2010). Most notable among them are those of seated females - the so-called "Mother Goddess". Artifacts from Sha'ar Hagolan are exhibited in the Israel Museum in Jerusalem, the Metropolitan Museum in New York and the Louvre in Paris.

Aside from its contribution to the Yarmukian culture of the Pottery Neolithic period, the site of Sha'ar Hagolan should be seen in its chronological and geographical context as well. The Jordan Valley is the earliest region in the world to encounter the agricultural revolution occurring between 12,000 and 6,000 BP, spanning the Natufian to Chalcolithic periods. Major sites in this period include 'Enan (Mallaha), Jericho, Netiv Hagdud, Munhata, Tel Zaf and Tulilat Ghassul (see below). After eleven excavation seasons nearly 3,000 sq.m. were unearthed at the site. Three discoveries are of great importance and should be presented to the public:

1. The courtyard monumental buildings (Figs. 2, 3). This architectural concept, of many small rooms built around a central courtyard is still popular today around the Mediterranean and the Near East. Sha'ar Hagolan is the oldest known example for this building concept.

2. A system of streets (Fig. 2). Two streets running from north to south, and one street running from east to west were found. This is one of the oldest street systems in the world.

3. The water well (Fig. 4).

There are many problems involved with opening the excavation areas to the public. These include preservation, reconstruction, fencing, car parking, movement of people in the site and explanation signs. One has to remember that the area suffers from a very hot summer, and there is need for shading some of the open areas for the benefit of the public. The ownership of the land is not a problem in this case, as the site is located in agricultural fields of Kibbutz Sha'ar Hagolan. ${ }^{1}$ But beyond the technical matters there is a need first to present a visiting concept to the entire site: what should be opened to the public, and how to present it? Shall we have some reconstructions? Is there a need for further excavations? The main problem here is that although monumental architecture was exposed in the site, it is offers little to the eye of non-professional visitor. Eventually, the excavation areas were covered by non-local soil type in 2004 to help their preservation as no solution for these issues was found.

Another attraction is the nearby Yarmuk river. As the river is the border between Israel and Jordan, it is closed behind the border fence and the public has no accesses to it. As the archaeological site is located on the river bank it is possible to build some observation post where the Yarmuk River can be seen by visitors. As two ancient streets lead to the river, a modern pathway can be built on the same line as the ancient ones, and the visitors will walk in the same streets exactly.

1 A 'kibbutz' is a communal form of settlement, established in the Land of Israel over 100 years ago, which originally followed socialistic ideals in a strict manner. 


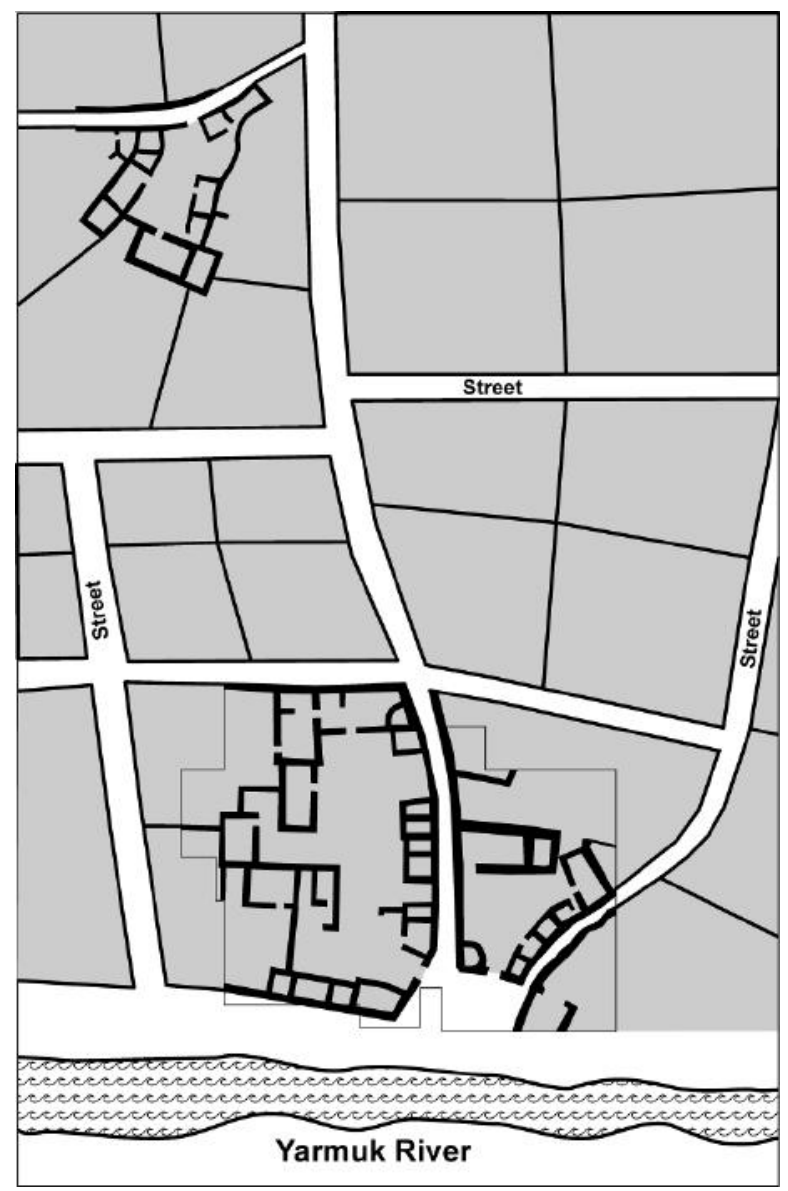

Figure 2. Sha' ar Hagolan site, schematic plan

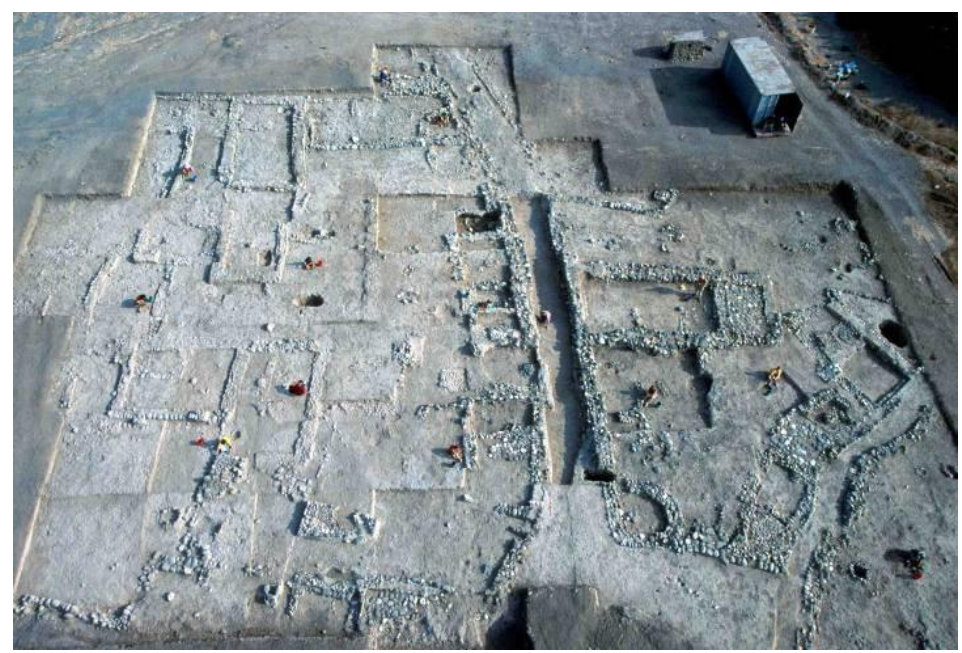

Figure 3. Sha'ar Hagolan Area E: general view 


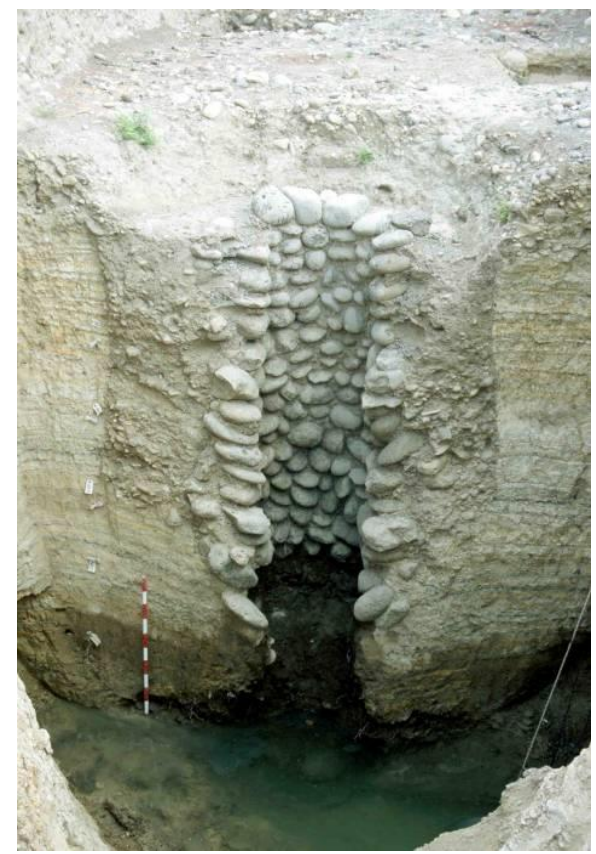

Figure 4. Sha 'ar Hagolan: The well

\section{Tel Tsaf}

The site of Tel Tsaf is located in the central Jordan Valley near Beth Shean on the west bank of the Jordan River (Fig. 1). The first excavation at the site was carried by Gophna (Gopha and Sadeh, 1988-89); it was a small scale probe. From 2004-2007, four excavation seasons were conducted at the site by Garfinkel on behalf of the Institute of Archaeology, Hebrew University of Jerusalem (Garfinkel et al., 2007a, 2007b, 2009; Ben-Shlomo et al., 2009). Currently from 2013 onwards a new team is excavating in the site by Danny Rosenberg of the University of Haifa and Florian Klimscha of the German Archaeological Institute in Berlin (Rosenberg et al., 2017).

Nearly 800 sq. $m$ of a densely built-up settlement were unearthed by the Hebrew University expedition. The site was occupied only during the Middle Chalcolithic period, for which a date of 5200-4500 Cal BC (period definitions follow Garfinkel, 1999) has been established on the basis of eight radiometric dates. According to surveys the size of the Chalcolithic site may have reached 20 hectares at its peak, yet it is difficult at this stage to estimate its population. The excavations exposed a composite array of courtyard buildings combining rectilinear rooms (Fig. 5), rounded rooms and 19 rounded silos (Fig. 6), which are located within large open courtyards. To the south of the main area a contemporary water well shaft was excavated (Fig. 7).

Building I had two stratigraphic phases with rounded silos and many cooking installations, both regular hearths and earth ovens (Figs. 5, 6). The upper phase is characterized by more numerous cooking facilities, which may indicate that feasts were held in the courtyard of the building from time to time. The silos from Tel Tsaf are located within the household courtyards, but their capacity seems far beyond the needs of a nuclear family. The common estimation of a person's consumption of cereals per year is around $200 \mathrm{~kg}$ (Mazar, 2001, 458). Thus a nuclear family does not need more than 1.5 tons of cereals per year, while the storage capacity of the courtyard structures at Tel Tsaf is 10 to 20 times larger, between 15 and 35 tons (Garfinkel et al., 2009, Table 1). We therefore seem to have a clear indication of large-scale surplus. To accumulate such amounts of grain was also beyond the working capacity of a single family. Perhaps this evidence may indicate an economic system with 'landlords' owning large territories of land cultivated by 'serfs' or 'tenants'. In any case the storage strategies employed at Tel Tsaf must have involved some kind of long range planning and can be construed as evidence for social complexity and some degree of administration, at least on the local scale. A further link to 
administration and possibly to redistribution may be provided by a stone seal and 140 clay sealings found in the site.

Four human burials from Tel Tsaf were all found in association with the silos (two inside a silo and the two others beside a silo). These were burials of selected individuals from the community, possibly people of higher status. One individual was buried with 1668 beads placed on the frontal part of the pelvis, organized in six rows (Garfinkel et al., 2007b, 2009, Fig. 9). Other important features located in these dwellings are large single-use cooking facilities, interpreted as earth ovens or fire pits. They attest to feasting activities at the site together with pits full of pig bones (Ben-Shlomo et al., 2009).

In another area of the site, Area B, a water well dated to the same period was excavated (Fig. 7). At the bottom of this well over 20 complete pottery vessels were found many with a pair of handles on each side. These vessels are most suited to draw water from the well as they can be balanced securely with a rope. From time to time, however, a vessel slipped in and was deposited at the bottom. The well as at the site of Sha'ar Hagolan testified public efforts in a construction project. The motivation for digging wells must had been the better quality of well water, or considerations of convenience, since the site is close to the Jordan River.

The material culture of Tel Tsaf is remarkably rich and complex. The pottery assemblage includes a significant amount of locally produced, elaborately decorated pottery ("Tel Tsaf Ware"), which is not found in other Chalcolithic sites in Israel (Garfinkel, 1999, 186-88). Five sherds of 'Ubaid pottery were also recognized at the site, imported from either north Syria or Mesopotamia and have not been found previously in the southern Levant. Important small finds include 15 obsidian items, probably sourced from Turkey. These may indicate the continuing import of this material from the Neolithic and Early Chalcolithic periods. In addition, over 2,500 beads of ostrich egg shell were found at the site.

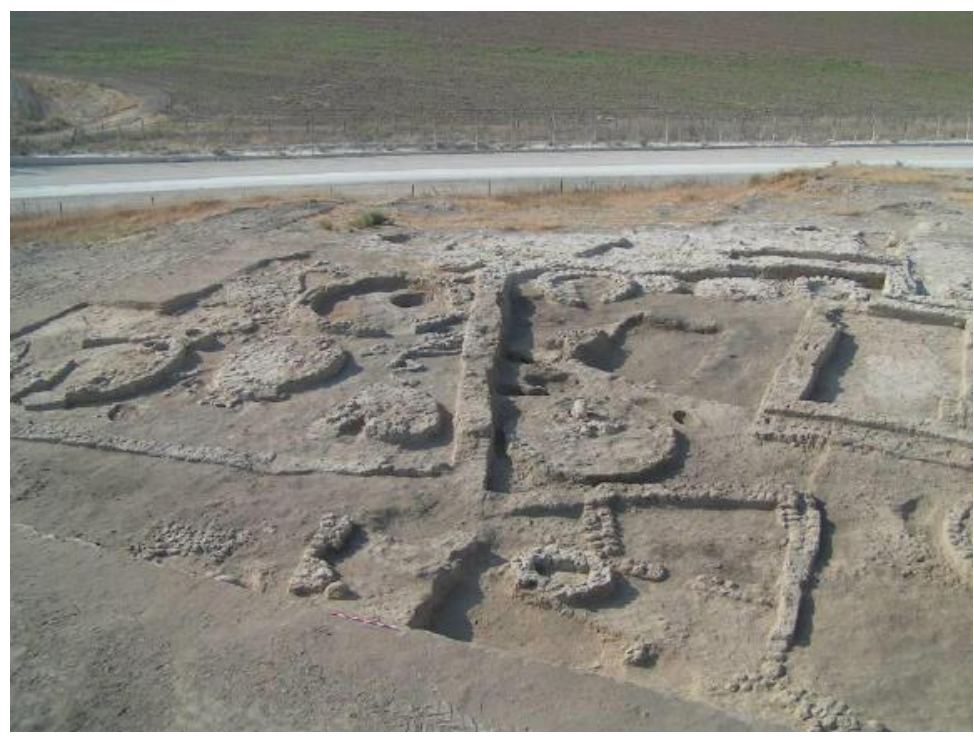

Figure 5. Tel Tsaf general photo of main area (Area C) 


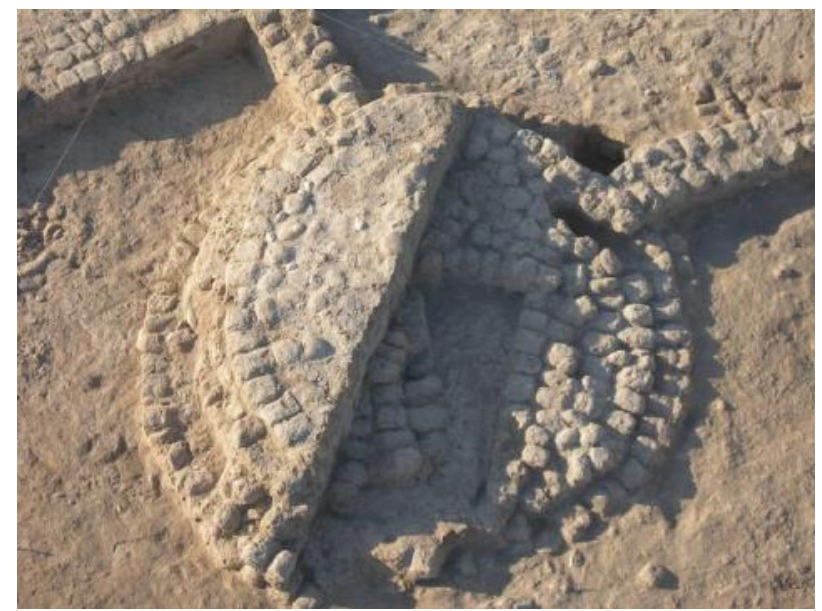

Figure 6. Tel Tsaf: A silo

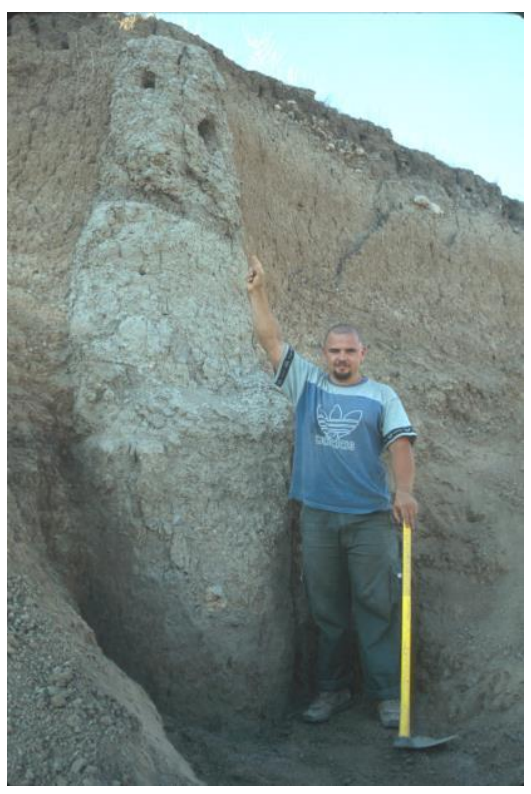

Figure 7. Tel Tsaf: The well

\section{Heritage and Educational Related Programs}

\section{Sha'ar Hagolan}

Near the site, at the Kibbutz of Sha'ar Hagolan several facilities and activities were already launched in previous decades (Fig. 8). An educational heritage center have been suggested already some 15 years ago (Garfinkel, 2004; Garfinkel and Ben-Shlomo, forthcoming), yet, did not yet materialize. The target is to transfer this knowledge to school classes, over a million tourists visiting the Sea of Galilee every year, and the general public. Keeping in mind the necessity for a 'critical mass' and an agglomeration of prehistory-related establishments, four different aspects may be developed, as follows: a museum, the excavated area, a reconstructed village ('A Journey through Time') and a pottery gallery (Figs. 8, 9). Of these four elements, the archaeological museum in Kibbutz Sha'ar Hagolan and the excavated areas already exist. 
In order to complete the picture it should be mentioned that Kibbutz Sha'ar Hagolan runs a large guesthouse, with bed-and-breakfast facility of ca. 250 beds. This compound is located near the museum, the kibbutz dining room and a large swimming pool. Into this environment a center for prehistory can be easily integrated. The local people in the tourist industry understand this situation and encourage further developments.

The Museum for the Yarmukian Culture: Over the years members of Kibbutz Sha'ar Hagolan have collected many Neolithic artifacts in the fields surrounding the kibbutz, especially the local fishponds. These included mostly flint, stone objects, pottery sherds and figurines. In 1950 Yehudah Roth and Mordechai Golani, two kibbutz members, organized these finds in a bomb shelter as the first prehistoric museum in Israel. During the 1970's the kibbutz of Sha'ar Hagolan succeeded in constructing a new spacious building housing the museum. In the early 1990's, the museum went through a process of upgrading, adding many visual and audio effects. In order to bring the prehistoric culture to as broad as audience as possible the strategy was to present less written text with more visual effects, and in some cases interactive devises. Additional visual information is given on the evolution of human culture during the prehistoric and proto historic periods. The museum contains a full overview of the Yarmukian culture including authentic assemblages of pottery, stone vessels, flint, and art objects. There is a library and a lecture hall with a video screening and a slide projector. A twelve minute video presents the visitor with the basic information on the site and the ancient culture. To this we can add movies and lectures illustrating the prehistoric cultures of the entire region.

The museum is managed by the local kibbutz community, and is promoted by the local tourism center of the kibbutz. Additional financial help is given every year by the Jordan Valley regional council and the state (The Museums council, Ministry of education). The entrance fee is nominal (about $3 €$ ) and every visitor is given a general explanation from a local employee. The yearly visitation stands at about 12,000.

Another activity is a pottery workshop, mainly aimed for children, that was launched in collaboration with the guesthouse and the museum. The groups include up to 20-25 children and can participate in all stages of pottery making: quarrying of the clay, treatment of the clay, making vessels and ceramic objects, decorating them and finally firing the vessels in an open fire kiln. The vessels made are typical of Yarmukian forms, decorated and fired in techniques that were probably used by the ancient people. The children can come from various sources: school groups coming for a single day visit, families staying in the guesthouse, or groups coming for longer camps of several days (also staying in the guesthouse). Similar activities for adults can also be organized. The price of such a workshop, which can be as low as 2-3€ per person, can cover the costs of both materials and man-power. Several youth groups have participated in this workshop, including an institute for mentally handicapped children. Another notable example is a group of Israeli-Palestinian terror victim families.

It should be noted that the prehistoric culture is optimally suited for joint Arab-Jewish educational projects, as it is devoid of the historical and religious baggage carried by other historical sites. The pottery workshop is considered as a pilot venture, and possibilities of largely expanding these activities are considered. Such activities may include pottery workshop or flint knapping summer camps lasting a week. Another type of summer camp is an archaeological tour camp including visit and study of prehistoric and historic sites in northern Israel (including the Mount Carmel caves, Neolithic and Chalcolithic sites, and historic tell sites such as Megiddo, Beit Shean and Hazor). Similar activities are also considered with relation to the proposed prehistoric reconstructed village. The importance of these activities is obvious: they combine education for prehistory to the general public through recreation. From an economic point of view it contributes to the local tourism industry.

Prehistoric and modern art: During the last seasons and after the excavations at the site finished another activity that was launched was related to cooperation with modern artists (poets, painters and sculpturers), creating modern art with the inspiration of the proto-historic site, culture and art. The highlight of this activity was the creation and erection of three large sized stainless steel sculptures created in the inspiration of pottery Neolithic 
pebble figurines and their schematic abstract nature. The sculptures are by the artist Tamara Rikmann and are situated near the local museum (Garfinkel et al., 2010, 343, Fig. 11.1).

\section{The Prehistoric Center of Sha'ar Hagolan}

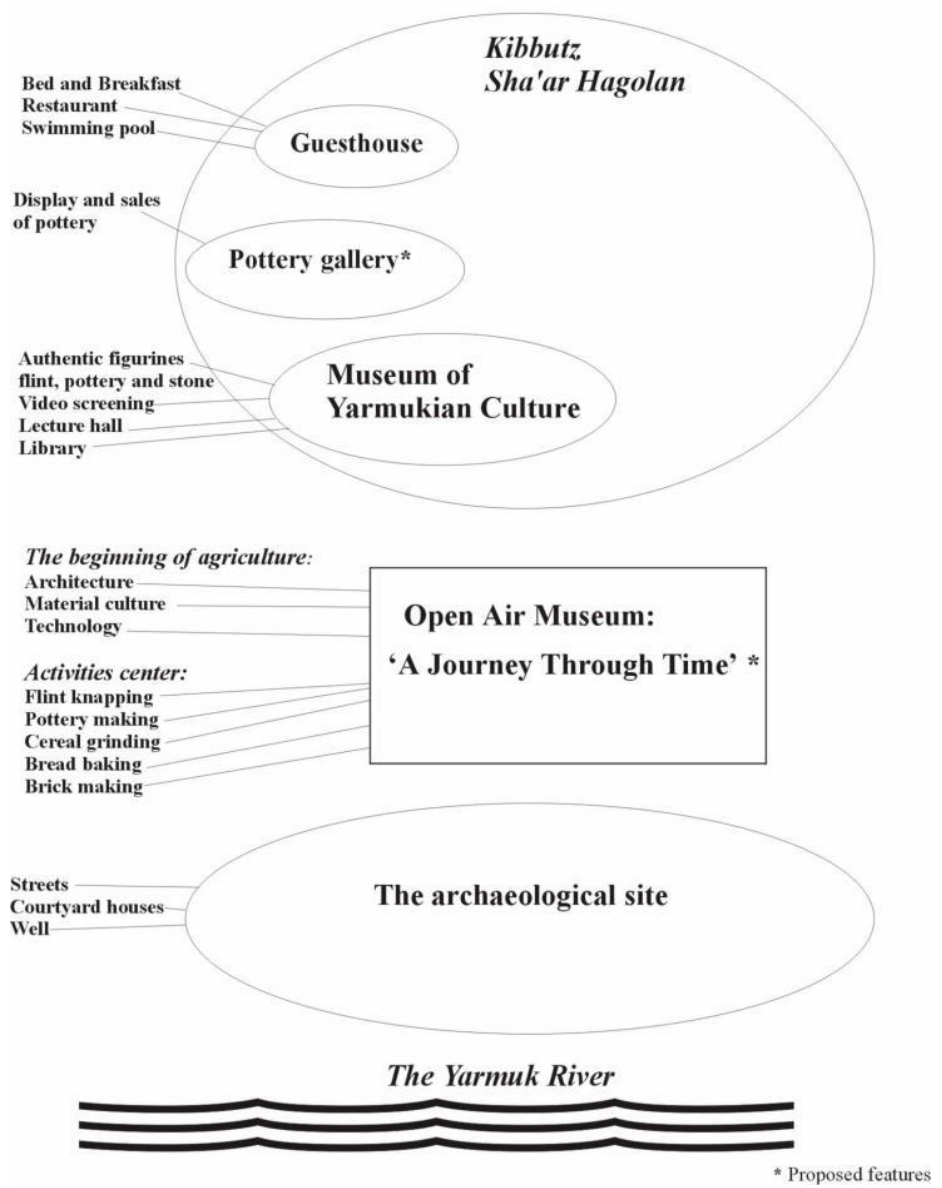

Figure 8. A schematic map of the components of the center for prehistory and proto-history at Kibbutz Sha'ar Hagolan.

The Proposed Prehistoric Village - 'A Journey through Time': The main component of the proposed prehistoric center at Sha 'ar Hagolan is an open air, life-size, "Prehistoric Village" that will focus on the major development of human evolution, the beginning of agriculture (Fig. 9). This process took place in the Jordan Valley 12,000 to 6,000 years ago. This open-air museum will be located physically and conceptually as a bridge between the past (Fig. 8, the archaeological site) and the present (the modern Kibbutz of Sha'ar Hagolan), thus, creating indeed a 'Journey through time'.

The prehistoric village will include reconstruction of five or six houses, each representing a different period (Fig. 9): Natufian, Pre-Pottery Neolithic A (PPNA), Pre-Pottery Neolithic B (PPNB), Pottery Neolithic and Chalcolithic. The life size reconstruction is based on authentic structures excavated in the Jordan Valley. Each house will be furnished according to the period it represents, and in an adjacent open area relevant outdoor activities and industries will be demonstrated (see Table 1). The houses will be arranged in chronological order around a central activity area; each house will be built in a depression, surrounded by native vegetation isolating it from its surroundings and accessed by a footpath. 
The earliest structure is a rounded hut, partly built in a pit from the Natufian site of 'Einan (Perrot, 1960, Fig. 10; Bar-Yosef ,1992, Fig. 1). The hut could be furnished with a hearth, stone mortars, flint tools and a model of a domesticated dog. The second house would be a rounded house from Netiv Hagdud of the PPNA period (BarYosef, Gopher and Gorring-Morris, 1980, Fig. 2); furnishing may include querns, reed baskets and flint tools. The third structure is rectangular house with plastered floors, based on a PPNB house from Jericho (Kenyon 1981, Pl. 221). Within the house querns, textiles, flint tools, modeled skulls, a plastered stature, a stone mask and a domesticated goat can be displayed. An installation for lime production may be reconstructed adjacent to the house. The fourth structure is a courtyard building excavated at Pottery Neolithic Sha'ar Hagolan (Garfinkel and Ben-Shlomo, 2002a, Figs. 5.6-5.7). In the courtyard and the rooms mortars, pottery and stone vessels, flint tools, figurines and models of domesticated cattle and pig will be displayed. Outside the structure a simple open fire pottery kiln and a water well will be reconstructed. From the early/middle Chalcolithic period another courtyard house (not shown in Fig. 9) and a grain silo can be reconstructed according to the finds at Tel Tsaf (see above). The last is a late Chalcolithic courtyard house based on houses excavated at Fasael (Porath, 1985, Fig. 2) and Teleilat Ghassul (Lovell, 2001, Fig. 1.2). In the house typical pottery, stone and copper objects, wall painting and a domesticated donkey will be displayed. Near the house simple copper smelting can be demonstrated as well as a burial cave with ossuaries. The houses and their furnishing will be constructed of authentic materials available in the region: mud, wood, basalt and limestone and straw. The wear of the more delicate furnishing items should be taken into account, possibly protected by fencing.

The exhibition of the prehistoric houses and their furnishing will enable the visitor to appreciate the evolution of the world's earliest village communities illustrated in architecture, material culture, technology, agriculture, ritual and burial customs. 


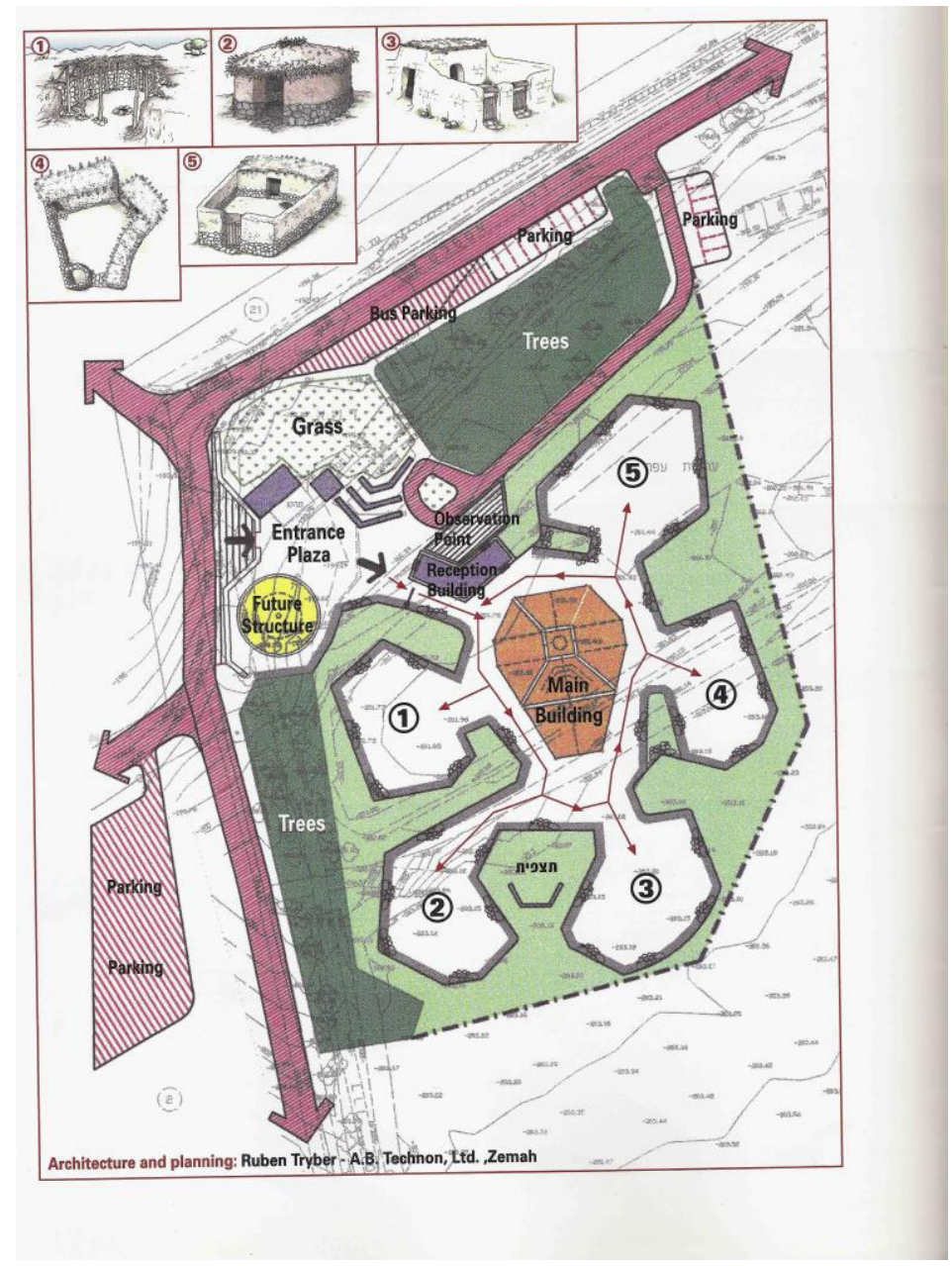

Figure 9. The plan of the proposed open air prehistoric village.

The central area of the open-air museum will include a large shaded open space, about 600 sq.m. (Fig. 9). Here, the visitors will perform activities characteristic of the relevant periods. Visitors will experience flint knapping, grain grinding, pottery making, weaving, primary copper metallurgy, skull plastering, dance, wall painting etc. The products will be taken by the visitors as souvenirs. Similar activities were conducted by staff and volunteers during the excavation seasons at Sha'ar Hagolan and in the pottery workshop associated with the museum. These include flint knapping pottery making, pottery firing, brick making and brick construction.

The materials and equipment needed for the activities can be portable and organized in a central area upon demand. The activities will be organized by the permanent staff of the center and aimed at school fieldtrips during the weekdays and families with children in the weekends. Encountering prehistoric culture through personal experience will highly improve the educational significance of the center and will bring the public closer to the prehistoric heritage. The main aspects to be emphasizes are:

1. The beginning of permanent settlement and architecture.

2. The agricultural revolution and animal domestication.

3. Flint knapping.

4. The earliest pottery manufacture.

5. Building mud houses. 
6. Other proto-historic industries (lime, copper).

7. Prehistoric art and cult.

Other components of the prehistoric village will include an entrance building with a ticket booth, offices, store, restroom facilities and guides room. The main season of activity would probably be during the school year in the autumn-winter and spring and less so during the summer. This takes into account the extremely hot weather of the summer months in this area, since this is an open air site. Another option is to build a closed air-conditioned complex. However, this option is inferior because of both environmental aspects and the high construction and running costs. ${ }^{2}$

The construction and operation of the prehistoric village will take place in four stages.

Phase 1: Preparation of construction plans and economic calculations;

Phase 2: Land clearance, landscaping and infrastructure;

Phase 3: Building of the entrance structure, shaded area, prehistoric houses and other facilities.

Phase 4: Furnishing of the houses, training the staff and final preparation for the operation of the center.

Table 1. Prehistoric Village Structures and Activity Areas

\begin{tabular}{|c|c|c|c|c|c|c|}
\hline Period & Site & Architecture & $\begin{array}{l}\text { Daily use } \\
\text { Implements }\end{array}$ & Technology & Art and cult & Activity area \\
\hline Natufian & 'Einan & Circular & $\begin{array}{l}\text { Flint tools, } \\
\text { deep mortars }\end{array}$ & & Sea shells & $\begin{array}{l}\text { Flint knapping, } \\
\text { Grinding \& bread } \\
\text { making }\end{array}$ \\
\hline PPNA & $\begin{array}{l}\text { Netiv } \\
\text { Hagdud }\end{array}$ & Circular & $\begin{array}{l}\text { Flint tools, querns, } \\
\text { reed basketry }\end{array}$ & & figurines & Bow \& arrow makin \\
\hline$P P N B$ & Jericho & $\begin{array}{l}\text { Rectangular, } \\
\text { plastered floor }\end{array}$ & $\begin{array}{l}\text { Flint tools, } \\
\text { querns, textiles }\end{array}$ & Lime kiln & $\begin{array}{l}\text { Sculpture, mas } \\
\text { Plastered skul] }\end{array}$ & $\begin{array}{l}\text { Body-painting, dance } \\
\text { masks }\end{array}$ \\
\hline $\begin{array}{l}\text { Pottery } \\
\text { Neolithic }\end{array}$ & $\begin{array}{l}\text { Sha'ar } \\
\text { Hagolan }\end{array}$ & $\begin{array}{l}\text { Courtyard } \\
\text { house }\end{array}$ & $\begin{array}{l}\text { Pottery, flint, } \\
\text { mortars }\end{array}$ & Pottery kiln & Figurines & Pottery making \\
\hline $\begin{array}{l}\text { Early } \\
\text { Chalcolithi }\end{array}$ & Tel Tsaf, & $\begin{array}{l}\text { Courtyard } \\
\text { House, silos }\end{array}$ & $\begin{array}{l}\text { Pottery, flint, } \\
\text { mortars }\end{array}$ & $\begin{array}{l}\text { Administrati } \\
\text { (sealings), } \\
\text { Pottery kiln }\end{array}$ & Figurines & Pottery making \\
\hline $\begin{array}{l}\text { Late } \\
\text { Chalcolithi }\end{array}$ & Fasael & & $\begin{array}{l}\text { Copper, pottery, } \\
\text { flint, basalt vessels }\end{array}$ & Copper kiln & $\begin{array}{l}\text { Wall painting, } \\
\text { ossuaries }\end{array}$ & $\begin{array}{l}\text { Weaving, copper } \\
\text { working, } \\
\text { butter churning }\end{array}$ \\
\hline
\end{tabular}

Proposed Pottery Gallery: The beginning of pottery production took place in the Yarmukian culture. Thus, Sha'ar Hagolan can be the location of a proposed large pottery gallery, where modern potters will present and sell their works. There are many modern potters in Israel, and in every main city one can find a pottery gallery where such artists offer their products. There is no central place for them, and there are many potters who have

\footnotetext{
2 A very offhand and initial calculation of the cost of this project as an open air museum would be about 500,000€ for Phases 1 and 2 ; $400,000 €$ for Phase 3; 400,000 $€$ for Phase 4 and a trial operation period of five years. The running cost taken into account a staff of 2 to 3 qualified persons full time: 1 administration and 1 or 2 guides. It takes into account the possibility that perishable equipment and materials for the activities will be covered by the entrance fees. As the structures will be constructed from authentic materials, yearly maintenance of the mudbrick houses will be required. The aim is that the center will eventually cover its costs, roughly estimated at $80,000 €$ per year. If a $3-5 €$ entrance fee will be charged this can be achieved by a yearly visitation of 20,000 to 30,000 people. Such a yearly visitation rate is reasonable according to data from regional tourist sites as el-Hama and sites in the region of the Sea of Galilee. Additional visitation could derive from pottery and "Mother Goddess" seminars and workshops conducted in the center.
} 
no connection to a local gallery, and thus have no way of displaying their work. In the centers of cities the rent is very high and the pottery galleries are rather small with a limited space. In Kibbutz Sha'ar Hagolan, in a rural area, the rent is minimal, and it is not expensive to open a large, national scale, pottery gallery. This will be another attraction that the place can offer to visitors. During the main holidays, when hundred of thousands of people are traveling in the area around the Sea of Galilee, a national pottery bazaar can be organized, attracting people who are specifically interested in modern potter' works. The pottery gallery is a pure economic establishment, but nevertheless can add another significant dimension to Sha'ar Hagolan. Part of the gallery can deal with ancient pottery production, but, more importantly, it will cater for modern pottery artists. This will be a center where potters from all over the country, and beyond, could exhibit and sell their works. These works may be inspired by prehistoric pottery and art but not necessarily so. This could also be a center for meetings, seminars and lectures on the topic of pottery.

\section{Tel Tsaf}

For the site of Tel Tsaf no heritage or educational program have yet been planned or suggested. The preservation and mudbrick construction poses difficulties for site reconstruction and preservation. A possible solution would be covering the excavation areas with a roof. Moreover, the area of the site is relatively remote, and far from the highway and modern settlements (the closest is Kibbutz Tirat Zvi, a religious community, which is about $3 \mathrm{~km}$ away to the northwest). This poses difficulties for advancing a cultural heritage and educational center. Nevertheless, if the area will be further developed in the future, possibly as a joint venture with the Kingdom Jordan, just across the Jordan River, new possibilities could arise. Such, would be a regional educational center for the culture of the Jordan Valley in pre- and proto-historic periods. Yet, currently in terms of heritage and education this site is rather problematic as it stands now and future projects are possible but may be highly costly and complicated.

\section{Conclusions}

While Proto historic archaeological sites create a special challenge for heritage management and education, they also pose a certain advantage in comparison with later archaeological sites in the region. These proto-historic sites, predate the rise of monotheistic religions, Judaism, Christianity and Islam, from the past and present political, ethnic and religious conflicts in the region stemmed. In the Near East, this could in fact serve as an advantage for heritage and educational management, since such sites and their culture can bypass current political and ideological disagreements and conflicts in the Middle East which are national or religion based, and thus approach and serve larger and more diversified audiences. They can also be a base for international cooperation.

The program presented here for a centre for prehistory at Kibbutz Sha'ar Hagolan is based on the approach of an agglomeration of establishments in a confined location, creating a higher rate of interest and attraction for the public. On the one hand, the archaeological site and the museum present authentic ancient material. On the other hand, the proposed reconstructed open-air village is totally modern. Thus, a physical separation exists between the ancient data, and its modern interpretation. While the public cannot walk directly on the ancient road, or hold the real figurines in his hand in the reconstructed village everything will be available to the public. This is the natural location of the proposed workshops.

Even if only a part of the projects suggested here will take place in the near future, we believe that striving for such a large-scale center is the best way to ensure that the public will have enough interest in the place to sustain it. Although some financial public support is given to museums and heritage sites, we believe that the optimal situation is that such a center could support itself financially. It is well known that the public financing of such establishments cannot be continuously relied on for long periods of time. However, with the combination of school groups, families, summer camps, pottery artists and feminists the center for prehistory can flourish. 
Sha'ar Hagolan is located in the border meeting of three countries: Israel, Jordan and Syria, while the Palestinian Authority is less than an hour's drive. Tel Tsaf is also located close to this region, $30 \mathrm{~km}$ to the south. The fact that these sites, as well as other regional sites, represent an authentic world heritage pre JudeoChristian-Islamic culture has clear advantages. The Jordan Valley is also the cradle of humanity outside Africa, as it lies on the route where ancient hominines and humans travelled out of Africa from about two million years ago onwards. This heritage can create a neutral ground presenting a narrative that will overcome political and religious differences of the populations in the region. Therefore, a prehistoric heritage center will serve as a meeting point where both Arab and Jewish youth will experience mutual recreation and education.

\section{References}

Ardery, R., 1967, The Territorial Imperative. A Personal Inquiry into the Animal Origins of Property andNations (London: Collins).

Bar Yosef, O., 1992, Building Activities in the Prehistoric Periods Until the End of the Neolithic Period. In The Architecture of Ancient Israel, A. Kempinski and R. Reich (eds.) (Jerusalem,Israel Exploration Society), pp. 3139.

Bar Yosef, O., Gopher, A. and Gorring-Morris, A.N., 1980, Netiv Hagdud: A "Sultanian” Mound in the Lower Jordan Valley. Paléorient 6, 201-206.

Ben-Shlomo, D., Hill, A.C. and Y. Garfinkel, 2009, Feasting between the Revolutions: Evidence from Chalcolithic Tel Tsaf, Israel. Journal of Mediterranean Archaeology 22/2, 129-150.

Garfinkel, Y., 1999, Neolithic and Chalcolithic Pottery of the Southern Levant (Qedem 39, Jerusalem, Hebrew University).

Garfinkel, Y., 2004, The Goddess of Sha'ar Hagolan. Excavations at a Neolithic Site In Israel (Jerusalem: Israel Exploration Society).

Garfinkel, Y. and Ben-Shlomo, D. 2002a. Yarmukian Architecture and Village Planning at Sha'ar Hagolan. Sha'ar Hagolan Vol 1. Neolithic Art in Context, Garfinkel, Y. and Miller, M.A. (eds.) (Oxford, Oxbow), pp.5570 .

Garfinkel, Y. and Ben-Shlomo, D., 2002b, Sha'ar Hagolan Architecture in its Near Eastern Context. Sha'ar Hagolan Vol 1. Neolithic Art in Context, Garfinkel, Y. and Miller, M.A. (eds.) (Oxford, Oxbow), pp. 71-85.

Garfinkel, Y. and D. Ben-Shlomo. 2009, Sha'ar Hagolan 2. The Rise of Urban Concepts in the AncientNear East (Qedem Reports 9, Jerusalem, The Hebrew University of Jerusalem).

Garfinkel, Y. and Ben-Shlomo, D., Forthcoming, Sha'ar Hagolan: A Center for Prehistoric Heritage in the Jordan Valley. In I. Hodder ed. Bringing the Past to Diverse Communities: Management and Education in Mediterranean Prehistory. Cambridge.

Garfinkel,Y., Ben-Shlomo, D. and Korn, N. 2010. Sha'ar Hagolan 3. Symbolic Dimensions of the Yarmukian Culture: Canonization in Neolithic Art (Jerusalem, Israel Exploration Society).

Garfinkel, G., Ben-Shlomo, D., and Marom, N., 2011, Sha'ar Hagolan: A Major Pottery Neolithic Settlement and Artistic Center in the Jordan Valley. Eurasian Prehistory 8 (1-2), 97-143.

Garfinkel, Y. and Miller, M. (eds.), 2002, Neolithic Art in Context: Sha'ar Hagolan 1 (Oxford, Oxbow Publications.

Garfinkel, Y., Ben-Shlomo, D., Freikman, M. and Vered, A., 2007a, Tel Tsaf: The 2004-2006 Excavations

Seasons. Israel Exploration Journal 57/1, 1-33.

Garfinkel, Y., Ben-Shlomo, D. and M. Freikman, 2007b, Tel Tsaf (Notes and News). Israel Exploration Journal 57/2, 236-241.

Garfinkel, Y., Ben-Shlomo, D. and T. Kuperman, 2009, Large-scale Storage of Grain Surplus in the Sixth Millennium BC: The Silos of Tel Tsaf. Antiquity 83, 309-325.

Gophna, R. and Sadeh, S., 1988-89, Excavations at Tel Tsaf: An Early Chalcolithic Site in the Jordan Valley, Tel Aviv, 15-16, 3-36.

Kenyon, K.M., 1981, Excavations at Jericho, Volume III (London, The British School of Archaeology in Jerusalem). 
Lovell, J.L., 2001, The Late Neolithic and Chalcolithic Remains in the Southern Levant. New Data from the Site of Telleilat Ghassul, Jordan (Oxford, B.A.R. International Series No. 977).

Mazar, A., 2001, The Significance of the Granary Building at Beth Yerah, in S.R. Wolff (ed.), Studies in the Archaeology of Israel and the Neighboring Lands in Memory of Douglas L. Esse (Studies in Ancient Oriental Civilizations 59, ASOR Books 5, Chicago, The Oriental Institute), pp. 447-464

Perrot, J., 1966, La gisement natoufien de Mallaha (Eynan) Israel. L'Anthropologie 70, 437-483.

Porath, Y., 1985, Chalcolithic Building at Phasa'el. 'Atiqot 17, 1-19.

Stekelis, M., 1972, The Yarmukian Culture of the Neolithic Period (Jerusalem, Magnes Press). 